\title{
Experience with alendronate treatment for four years among Japanese men with osteoporosis or osteopenia and clinical risk factors for fractures [Expression of concern]
}

\author{
Iwamoto J, Sato Y, Uzawa M, Takeda T, Matsumoto H. Ther- \\ apeutics and Clinical Risk Management. 2010;6:593-600.
}

The Editor-in-Chief and Publisher of Therapeutics and Clinical Risk Management wish to issue an Expression of concern for the above published article.

The Journal Editors received notification from an investigator raising concerns about the published paper. These concerns relate to the high similarity in content to the article Experience with alendronate treatment for 7 years among Japanese men with osteoporosis or osteopenia and clinical risk factors for fractures'. Iwamoto J, Uzawa M. Clinical Rheumatology. 2016;35:205-212. There were also concerns raised relating to the timeline for study conduct and manuscript preparation. The article reports the study took place between July 1st and
September 30th, 2010 and was submitted for publication on Oct 24, 2010.

Dove Medical Press attempted to contact the authors of the article and their affiliated institution regarding these concerns but received no response. As we were unable to make a definitive conclusion, we would like to alert readers to these issues and allow them to draw their own conclusions. This decision follows the recommendations of the Committee on Publication Ethics (COPE).

The Editor and Dove Medical Press make every effort to ensure publication ethics are upheld and are committed to supporting the high standards of the Therapeutics and Clinical Risk Management journal.
Therapeutics and Clinical Risk Management

\section{Publish your work in this journal}

Therapeutics and Clinical Risk Management is an international, peerreviewed journal of clinical therapeutics and risk management, focusing on concise rapid reporting of clinical studies in all therapeutic areas, outcomes, safety, and programs for the effective, safe, and sustained use of medicines. This journal is indexed on PubMed Central, CAS,

\section{Dovepress}

EMBase, Scopus and the Elsevier Bibliographic databases. The manuscript management system is completely online and includes a very quick and fair peer-review system, which is all easy to use. Visit http://www.dovepress.com/testimonials.php to read real quotes from published authors. 